\title{
Sources of pheromones in the lizard Liolaemus tenuis
}

\author{
Fuentes de feromonas en el lagarto Liolaemus tenuis
}

\author{
ANTONIETA LABRA ${ }^{1}$, CARLOS A. ESCOBAR ${ }^{2}$, PAZ M. AGUILAR ${ }^{3} \&$ HERMANN M. NIEMEYER ${ }^{3}$
}

\author{
${ }^{1}$ Departamento de Ecología, Facultad de Ciencias Biológicas, P. Universidad Católica de Chile, Casilla \\ 114-D, Santiago, 6513677, Chile; e-mail: mlabra@genes.bio.puc.cl \\ ${ }^{2}$ Facultad de Ecología y Recursos Naturales, Universidad Nacional Andrés Bello, Avenida República \\ 217, Santiago, Chile \\ ${ }^{3}$ Departamento de Ciencias Ecológicas, Facultad de Ciencias, Universidad de Chile, \\ Casilla 653, Santiago, Chile
}

\begin{abstract}
Experimental tests were conducted with the lizard Liolaemus tenuis (Tropiduridae), to determine the potential sources of pheromones used in its chemical communication, centered in the phenomenon of self-recognition. During the postreproductive season, feces of both sexes and secretions of precloacal pores (present only in males) were tested. Stimuli were presented to lizards spread on rocks, and the number of tongue-flicks (TF) to the rocks was used as a bioassay to determine pheromone recognition. Feces contained pheromones involved in self-recognition, since lizards showed less TF confronted to rocks with suspensions of their own feces than with suspensions of feces of conspecifics or with water (control). In order to assess the chemical nature of self-recognition pheromones, feces were submitted to a sequential extraction with three solvents of increasing polarity, thereby obtaining three feces fractions. There were no differences in TF towards rocks with different fractions with own feces. Additionally, lizards showed similar TF to rocks with fractions of own and conspecific feces, suggesting that the separation procedure broke up a complex stimulus into parts that were not active individually as pheromones. Finally, males did not discriminate between precloacal secretions from themselves and from another male. It is possible that these secretions convey information relevant to or detectable by females only.
\end{abstract}

Key words: self-recognition, Liolaemus, precloacal secretions, lizards, chemical discrimination, semiochemicals.

\section{RESUMEN}

Se realizaron pruebas experimentales con la especie Liolaemus tenuis (Tropiduridae), para determinar las potenciales fuentes de feromonas usadas en su comunicación química. El estudio se centró en el fenómeno de auto-reconocimiento. Durante la estación post-reproductiva, las fecas de ambos sexos y las secreciones precloacales (presentes sólo en machos) fueron probadas. Los estímulos fueron presentados a los lagartos esparcidos sobre rocas, y el número de lamidos (TF) a la roca fue utilizado como un bioensayo para determinar reconocimiento de feromonas. Las fecas contienen feromonas involucradas en auto-reconocimiento, ya que los lagartos realizaron menos TF confrontados con rocas con suspensiones de fecas propias que de un conespecífico o con agua (control). Con el objeto de evaluar la naturaleza química de las feromonas de auto-reconocimiento, las fecas fueron sometidas a una extracción secuencial con tres solventes de polaridad creciente, obteniéndose así tres fracciones de fecas. No existió diferencia en el número de TF hacia las distintas fracciones de fecas. Mas aún, los lagartos no mostraron diferencias en TF cuando fueron expuestos a fracciones fecales propias y de conespecíficos. Esto sugiere que el procedimiento de separación disgregó un estímulo complejo en partes que no son activas individualmente. Finalmente, los machos no discriminaron entre secreciones precloacales de ellos mismos y de otros machos. Probablemente estas secreciones sean portadoras de información relevante o detectable sólo por hembras.

Palabras clave: auto-reconocimiento, Liolaemus, secreciones precloacales, fecas.

\section{INTRODUCTION}

Chemoreception through the vomeronasal organ is an important sensory modality in lizards (Mason 1992), experimentally demonstrated in species of different families including Iguanidae, Phrynosomatidae, Eublepharidae, Gekkonidae, Scincidae, Gerrhosauridae, Lacertidae, Cordylidae, and Tropiduridae (Mason 1992, Cooper 1994,
Cooper et al. 1996, Labra \& Niemeyer 1999). Pheromones, i.e., semiochemicals involved in intraspecific communication (Meredith 1999), have been shown to be involved in sexual recognition (Cooper 1994, Cooper et al. 1996), territory marking (Alberts 1992a), avoidance of agonistic encounters (Cooper \& Vitt 1987a), kin recognition (Lena \& de Fraipont 1998), and mother-offspring recognition (Bull et al. 1994). 
Comparatively less is known about the sites where pheromones are synthesized and secreted. They can derive from specific organs such as femoral (Alberts 1993), precloacal (Cooper et al. 1994), or urodaeal glands (Cooper et al. 1986, Cooper \& Garstka 1987, Cooper \& Trauth 1992). Less specific sources can also be involved such as the exudates of the body surface (Mason \& Gutzke 1990, Bull et al. 2000) and feces (Duvall et al. 1987, Werner et al. 1987, Carperter \& Duval 1995, López et al. 1998, Bull et al. 1999a, 1999b, Aragón et al. 2000).

Evidence suggests that different Liolaemus lizards (Tropiduridae) have self, conspecific and congeneric chemical recognition (Labra \& Niemeyer 1999, Labra et al. 2001a, 2001b); however, the sources of pheromones involved in these processes have not been established. Secretions of precloacal pores, a set of structures mainly present in males of Liolaemus species (Cei 1986, 1993), have been suggested to play a role in chemical communication (Escobar et al. 2001). On the other hand, under laboratory and field conditions Liolaemus lizards frequently make tongue-flicks (TF) to feces (A. Labra personal observations). Because TF are commonly used as a bioassay for vomerolfaction (Cooper 1998), these observations suggest that feces may carry pheromones. We undertook herein a study of precloacal pores of males and feces of both sexes, as sources of pheromones in Liolaemus tenuis. The study was performed during the post-reproductive season, since during this period L. tenuis shows self-recognition (Labra \& Niemeyer 1999).

\section{MATERIAL AND METHODS}

Liolaemus tenuis was collected at El Ingenio

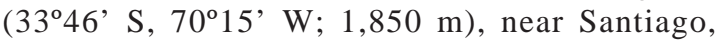
Chile. Seventeen individuals ( 9 males, 8 females) were captured by noosing during April - May (autumn) and taken to Universidad de Chile, where they were placed in an indoor vivarium with a 10L:14D photoperiod. Halogen lamps (350 W) provided environmental temperatures in a range between 13 to $32{ }^{\circ} \mathrm{C}$, similar to those recorded in nature during hot autumn days. Lizards were housed individually in plastic enclosures $(37$ x 30 $\mathrm{x} 15 \mathrm{~cm}$ ) containing a $2-\mathrm{cm}$ layer of sand. The cover of the enclosure and the wall directly exposed to light were made of a plastic mesh, allowing lizards to perform behavioral thermoregulation. Enclosures had a Petri dish for water, and a rock for basking and for shelter. Because diet may affect the semiochemicals perceived and used as pheromones (i.e., Walls et al. 1989), L. tenuis was exclusively fed with mealworms every other day. Once per week, food was dusted with reptile Vitamins and mineral supplements. Water was supplied ad libitum. Experimentation began after one week of habituation to enclosures.

\section{Samples and experiments}

Feces were collected twice a week with metal forceps previously cleaned with $95 \%$ ethanol and placed individually in labeled glass vials, which were sealed and stored at $-20^{\circ} \mathrm{C}$. Two hours before their use vials were thawed at room temperature. Simultaneously, two experiments were performed, and their trials were performed randomly. The first experiment was designed to determine if intact feces are a source of pheromones, and the second to determine the chemical nature of such pheromones. For the first experiment, one or two pellets of feces produced by an animal were crushed $(25.0 \pm 1.70 \mathrm{mg}, \mathrm{n}=17$; mean $\pm \mathrm{SE})$ in a mortar with $7.5 \mathrm{ml}$ distilled water for $10 \mathrm{~min}$, spreading the suspension over a clean rock (ca. $132 \mathrm{~cm}^{2}$ ). In this way we ensured that feces were a source of chemical and not of visual signals. Additionally lights used during experiments did not allow UV reflection from feces (see Alberts 1989). Treatments were rocks covered with suspensions of feces of the test individual (own feces) or of a conspecific of the same sex as the test individual (cosexual), or with distilled water (control).

Fractions of feces containing compounds of different polarities were obtained by subjecting a pool of feces $(155 \pm 13 \mathrm{mg})$ to three consecutive extractive treatments: (1) the pool was macerated in a mortar with dichloromethane $(7.5 \mathrm{ml})$ for 10 min and filtered through Whatman No. 2 paper. The filtrate containing the least polar compounds of feces (fraction 1, F1) was spread over a clean rock; (2) solids remaining on the filter paper were macerated in a mortar with ethanol $(7.5 \mathrm{ml})$ for 10 min and then filtered. The new filtrate (fraction 2, F2) was spread over a new clean rock; (3) solids remaining on the filter and comprising the most polar compounds were suspended in distilled water (fraction 3, F3) and spread over a third new clean rock. In this experiment treatments were rocks covered with fractions of own feces, of a cosexual, or solvent; dichloromethane, ethanol, or distilled water were the controls for fractions F1, F2, and F3, respectively.

Lizards were exposed randomly to 11 treatments in feces experiments. The trial with distilled water was performed only once.

After completing the experiments with feces, the orange-yellow waxy precloacal secretions of 
males were collected (see Escobar et al. 2001). There was no evidence of damage caused by the extraction. Secretions were weighed $(0.89 \pm 0.5$ $\mathrm{mg}$, mean $\pm \mathrm{SD}, \mathrm{n}=8$ ) and placed in vials containing dichloromethane $(400 \mu 1)$. The non-soluble part of secretions was removed by filtration. The solvent of the soluble part was removed under a stream of dry nitrogen, and the residue was frozen and maintained in individual vials at $-20^{\circ} \mathrm{C}$ until two hr before use. Extracts of precloacal secretions $(5 \mu \mathrm{g}$ of secretion in $4.5 \mathrm{ml}$ of dichloromethane) were spread over a clean rock. Males were exposed to rocks covered with extracts of secretions from themselves or from another male. Data from the control condition (rock spread with dichloromethane) were used from the previous experiments. Exploratory analyses indicate that there is no difference in the behavior confronted with different solvents; therefore we re-used data of control condition to avoid submitting lizards to unnecessary trials.

Experiments were performed between 10:30 and 15:00 h. Before exposing lizards to rocks with stimuli, solvents were evaporated by placing rocks in an oven at $43{ }^{\circ} \mathrm{C}$ for $1 \mathrm{~h}$. Thereafter, rocks were placed in the test enclosure (unused enclosure identical to the one used to maintain lizards) which had clean sand and a bowl with water. At the beginning of trials rocks had temperatures between $36{ }^{\circ} \mathrm{C}$ and $40{ }^{\circ} \mathrm{C}$, which facilitated experiments since lizards approached rocks to thermoregulate. Pilot trials showed that lizards took more than one hour to approach and lick a cold rock $\left(<30^{\circ} \mathrm{C}\right)$. Rocks and enclosures were used once, then washed thoroughly and dried. Sand was discarded.

The test individual was removed from its enclosure and placed in a fabric bag for $45 \mathrm{~min}$. Thereafter, it was placed in the test enclosure with a rock covered with some of the stimuli previously described. Lizards were released in the enclosure opposite to the rock. The number of TF to the rock was recorded during $10 \mathrm{~min}$ after the first TF to the rock. Observations were made from behind a curtain, and data were recorded using The Observer software (Noldus 1995).

Body temperature can affect the rate of $\mathrm{TF}$ (Cooper \& Vitt 1986a). Therefore, cloacal body temperatures were recorded using a $\mathrm{Cu}$-constantan thermocouple and a digital thermometer (DigiSense $\pm 0.1^{\circ} \mathrm{C}$ ) after experiments. If temperatures were not within two degrees of L. tenuis selected body temperature (Labra 1998), trials were discarded and repeated later. Additionally, if lizards retreated under the rock or failed to show TF within $20 \mathrm{~min}$, trials were canceled and postponed to a latter date. Lizards were tested every other day. Experiments with secretions of precloacal pores were started one week after extraction to avoid potential stress caused by manipulation.

Females were submitted to a total of 11 different treatments, and males to 13 treatments. Each lizard was tested only once, except when a trial needed to be repeated. At the end of the study, animals were returned in good conditions to the field.

Data for males and females were pooled since they showed non-significant differences. Because data were normally distributed and had homogeneous variances, one or two-way repeated-measures ANOVA tests followed by a posteriori multiple comparisons using Tukey's HSD test were used (Zar 1984). One-way ANOVA was performed to determine effects of treatments (own samples, from cosexual, and solvent) on TF in experiments with intact feces and precloacal secretions. Twoway ANOVAs were used to compare: (1) TF in experiments of fractionated feces with treatments (see above) and fractions as factors and (2) TF of males when factors were the source of stimuli (feces or precloacal secretions) and treatment (same as above). During the experiments with feces fractions two lizards escaped, so the final sample size was reduced to 15 .

RESULTS

Feces

Experiments with intact feces indicated that lizards reacted differently to treatments $\left(\mathrm{F}_{2,32}=7.23\right.$, $\mathrm{P}=0.003)$; they showed fewer TF to rocks covered with suspension of own feces, than to rocks covered with feces of cosexual or solvent (Fig. 1). Contrarily, when fractions of feces were tested, $\mathrm{TF}$ was unaffected by treatment $\left(\mathrm{F}_{2,28}=0.09, \mathrm{P}=\right.$ $0.92)$, type of fraction $\left(\mathrm{F}_{2,28}=0.65, \mathrm{P}=0.53\right)$ or their interaction $\left(\mathrm{F}_{4,56}=1.69, \mathrm{P}=0.16\right)$. Mean values of TF ranged between 6.67, in the case of males confronted with F1 of cosexual, and 9.53 when animal were confronted with F3 of conspecific.

\section{Precloacal secretions}

TF performed by males confronted to rocks with extracts of precloacal secretions was affected by treatment $\left(\mathrm{F}_{2,14}=7.59, \mathrm{P}=0.006\right)$. Males showed similar TF to rocks covered with own secretions and secretions from another male, and in both cases less TF than to rocks with solvent (Fig. 2). Comparisons of TF shown by males exposed to 


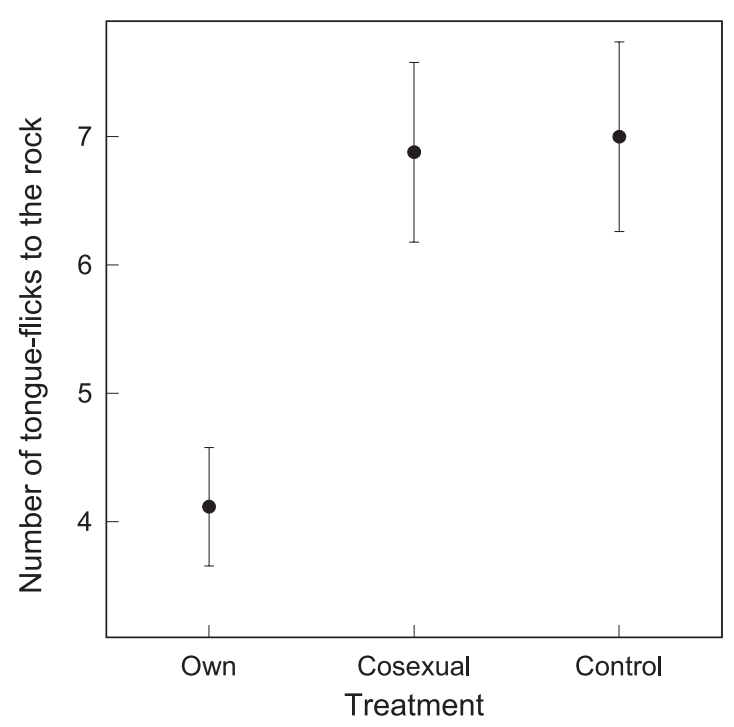

Fig. 1: Mean number of tongue-flicks to the rock ( $\pm \mathrm{SE}$ ) exhibited by Liolaemus tenuis. Rocks were covered with suspensions of feces in water. Treatments were rocks covered with suspensions of own feces, or that from conspecifics of the same sex as the lizards tested (cosexual), or with distilled water (control). Test period lasted $10 \mathrm{~min}$. Sample size per treatment $=17$.

Número promedio de lamidos a la roca $( \pm \mathrm{EE})$ realizados por Liolaemus tenuis. Las rocas fueron cubiertas con suspensiones de fecas en agua. Los tratamientos fueron rocas cubiertas con suspensiones de fecas propias, de un conespecífico del mismo sexo del lagarto que era probado (cosexual), o agua destilada (control). El período de prueba fue de $10 \mathrm{~min}$. Tamaño muestreal por tratamiento $=17$.

two sources of stimuli (feces or precloacal secretions) in three treatments, indicated that TF was affected by treatment $\left(\mathrm{F}_{2,14}=13.31, \mathrm{P}=0.0006\right)$. Males showed higher TF to rocks with solvents than with extractions of precloacal secretions or suspension of feces. The source of stimuli had no effect on $\mathrm{TF}\left(\mathrm{F}_{1,7}=1.42, \mathrm{P}=0.27\right)$. The interaction between factors was significant $\left(\mathrm{F}_{2,14}=6.50, \mathrm{P}=\right.$ 0.01). As shown in Fig. 2, males confronted to rocks with stimuli coming from another male had significantly fewer TF when rocks had precloacal secretions than feces $(P=0.02)$. No differences were found in TF performed to rocks with different solvents. In addition, males confronted with rocks with their own stimuli made no distinction between their source.

\section{DISCUSSION}

In squamates, the number of tongue-flicks is correlated with the ability to discriminate a vomodor
(Font 1996); hence, detection and recognition of stimuli is reflected in differences in the number of tongue-flicks among treatments (Cooper 1998). Additionally, different authors have proposed chemical self-recognition when lizards show fewer TF under conditions confronted to their own stimuli than with those of conspecifics (e.g., Bissinger \& Simon 1981, Alberts 1992a, López et al. 1997, Cooper et al. 1999, Aragón et al. 2001). The experiments with intact feces of L. tenuis strongly suggest that feces contain pheromones that allow self-recognition, since lizards performed fewer TF to rocks spread with their own fecal suspensions than with those from a cosexual or with water. One of the main functions attributed to self-recognition is that it may facilitate identification of territorial boundaries (Alberts 1992a), which may reduce agonistic interactions among individuals. In the case of L. tenuis this ability may be particularly relevant, since it is a territorial species (Manzur \& Fuentes 1979).

Some results with intact feces may be considered counterintuitive at first glance, e.g., lizards

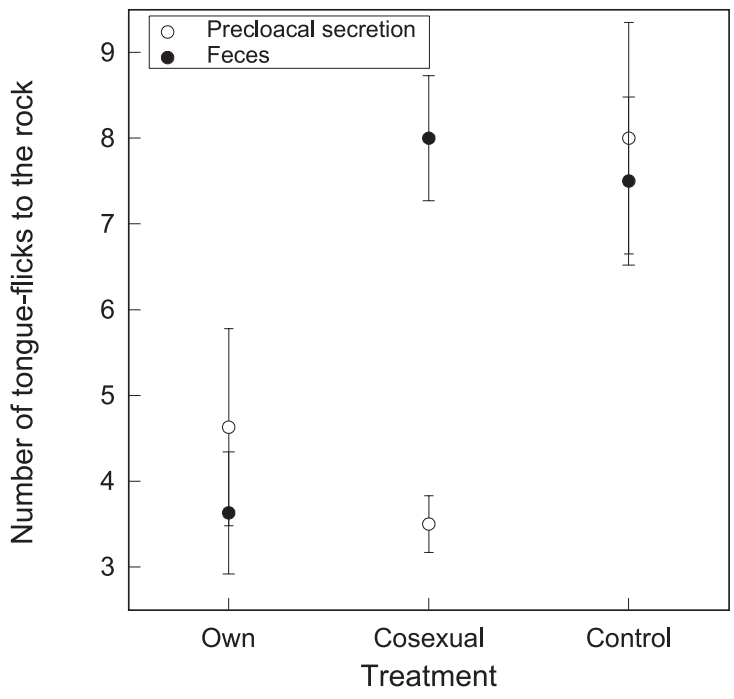

Fig. 2: Mean number of tongue-flicks ( \pm SE) performed by males of Liolaemus tenuis to rocks covered with dichloromethane extracts of precloacal secretions or suspensions of feces in distilled water. Treatments were males tested with rocks with their own samples, samples of other males (cosexual), or solvent (control). Test period lasted $10 \mathrm{~min}$. Sample size per treatment $=8$.

Número promedio de lamidos $( \pm \mathrm{EE})$ realizados por machos de Liolaemus tenuis a rocas cubiertas con extractos de secreciones precloacales en diclorometano o en suspensiones de fecas en agua destilada. Los tratamientos fueron machos enfrentados a rocas con sus propias muestras, con muestras de otros machos (cosexual), o con solvente (control). El período de prueba fue de $10 \mathrm{~min}$. Tamaño muestreal por tratamiento $=8$. 
had the same TF confronted with cosexual pheromones and with water, suggesting that lizards are indifferent towards a cosexual (but see Cooper 1998). Recently it was shown that discrimination ability in lizards can be effectively assessed by recording behaviors other than chemical exploratory ones (Labra \& Niemeyer 2001) ${ }^{1}$, or by electrophysiological recordings (Pausse et al. 1999). Since in this study we did not include other types of parameters that may be important to detect discrimination, we can not rule out the possibility that lizards do in fact discriminate between cosexual and water. Alternatively, it may be hypothesized that there may be constraints (e.g., physiological) to exploration, except in situations when males are highly motivated, such as by females during the reproductive season (Labra \& Niemeyer 1999, Labra et al. 2001a).

Many vertebrates use feces as visual and chemical signals to mark their territories, and sometimes the chemical effect is reinforced using urine (Alberts 1992b). Lizard feces contain digestive and urinary products, and may constitute chemical but also visual signals (e.g., Duvall et al. 1987, López et al. 1998). However, the experiments performed with L. tenuis were designed in such way as to avoid feces as visual cues. Thus, feces were presented as suspensions, and experimental light conditions did not allow UV reflection from feces, as has been reported earlier (Alberts 1989). If L. tenuis relies on chemicals in feces to mark territories, pheromones can be spread on the substrate by direct secretion or during defecation. Interestingly, lizards usually drag their cloaca after defecation (A. Labra unpublished results). The question whether feces are also used as visual signals by L. tenuis remains open.

The main type of molecules involved in chemical communication in squamates is still under discussion. While Alberts et al. (1993) proposed that pheromones are proteic in nature on the basis of the intraspecific variability in the protein composition of secretions of femoral glands, which are known to have pheromonal properties (Mason 1992), other studies have pointed to the lipidic nature of pheromones in Squamata (e.g., Cooper \& Garstka 1987, Mason \& Gutzke 1990, Bull et

\footnotetext{
${ }^{1}$ LABRA A \& HM NIEMEYER (2001) Chemosensory predator discrimination in Liolaemus lizards: effect of a geographical overlap with the predator. In: Apfelbach R, M Fendt, S Kramer \& BM Siemer (eds) Advances in Ethology 36. Supplement of Ethology. Contributions to the XXVII International Ethological Conference. Meeting Tubingen, Germany: 199. Blackwell Wissenschafts-Verlag, Berlin, Germany.
}

al. 1999b). The latter results are consistent with the lipidic nature of the vast majority of insect pheromones (e.g., Mayer \& McLaughlin 1991). The isolation of individual pheromones from a mixture showing pheromonal properties may be carried out by subjecting the mixture to chemical fractionation (Font 1996, Bull et al. 1999b). The results of subjecting feces of L. tenuis to sequential solvent extraction did not reveal either the nature or the polarity of L. tenuis self-recognition pheromones, since none of the fractions produced differential activity between treatments. Additionally, there was no difference between TF towards rocks with own and cosexual feces fractions. It is unlikely that the separation procedure employed chemically transformed and inactivated a single pheromone. It is more likely that fractionation broke up a complex pheromonal mixture into constituents which were not active individually. This is very frequently the case in insects, one of the most extensively studied classes of organisms in terms of pheromones (Mayer \& McLaughlin 1991).

The second source of pheromones tested was the secretions of precloacal pores. The number of these pores varies across Liolaemus species (Cei 1986,1993 ) and the chemical composition of the lipidic fraction of the secretions shows intra and interspecific difference (Escobar et al. 2001). In amphisbaenians the secretion of these pores has a pheromonal property (Cooper et al. 1994), so all the antecedents suggest that precloacal secretions in Liolaemus have pheromonal function. Indeed, L. tenuis males discriminate between precloacal secretions and solvent. However, males did not discriminate between themselves and other males through precloacal secretions. Therefore, although secretions seem to be involved in chemical recognition, they not allow males discriminate between themselves and other males. We propose that secretions convey information to males of a "male presence". Possible, males make a latter finer recognition through feces. However, considering that precloacal secretions show intra and interspecific differences in their chemical composition (Escobar et al. 2001) it is puzzling why these secretions do not convey more information to males. Alternative, precloacal secretions may have evolved to convey information mainly detectable or relevant for females or that they convey important information mainly during the breeding season. Interestingly, during this period secretions are more abundant and colorful (A. Labra unpublished results). Future research in this area should test if precloacal secretions are involved in functions such as female attraction, conveying information of male condition/quality 
(e.g., Martín \& López 2000). On the other hand, since many Liolaemus inhabit in sympatry, precloacal secretions may convey information about the species, thus acting as reproductive barriers as have been proposed for lizards of the Eumeces genus (Cooper \& Vitt 1986a, 1987a, 1987b) and for some mammals (Heth et al. 1999).

\section{ACKNOWLEDGMENTS}

The authors thank the Servicio Agrícola y Ganadero for lizard capture permit No. 3112, April 1999. The authors acknowledge financial support from the Presidencial Chair in Sciences awarded to HMN, International Foundation of Science grants 2933-1 to AL, and 2934-1 to CAE, and International Program in the Chemical Sciences at Uppsala University. This work is part of the research carried out at the Center for Advanced Studies in Ecology and Research in Biodiversity funded by the Millennium Science Initiative (P099-103F, ICM). M. Cuadrado and one anonymous reviewer made important suggestions to an early version of the manuscript.

\section{LITERATURE CITED}

ALBERTS AC (1989) Ultraviolet visual sensitivity in desert iguanas: implications for pheromone detection. Animal Behaviour 38: 129-137.

ALBERTS AC (1992a) Pheromonal self-recognition in desert iguanas. Copeia 1992: 229-232.

ALBERTS AC (1992b) Constraints on the design of chemical communication systems in terrestrial vertebrates. American Naturalist 139: S62-S89.

ALBERTS AC (1993) Chemical and behavioral studies of femoral glands secretions in iguanid lizards. Brain Behavior and Evolution 41: 255-260.

ALBERTS AC, JA PHILLIPS \& DI WERNER (1993) Sources of intraspecific variability in the protein composition of lizard femoral gland secretions. Copeia 1993: 775-781.

ARAGÓN P, P LÓPEZ \& J MARTÍN (2000) Size-dependent chemosensory responses to familiar and unfamiliar conspecific faecal pellets by the Iberian rocklizard, Lacerta monticola. Ethology 106: 1115-1128.

ARAGÓN P, P LÓPEZ \& J MARTÍN (2001) Discrimination of femoral gland secretions from familiar and unfamiliar conspecifics by male Iberian rocks-lizards, Lacerta monticola. Journal of Herpetology 35: 346-350.

BISSINGER BE \& CA SIMON (1981) The chemical detection of conspecifics by juvenile Yarrow's spiny lizard, Sceloporus jarrovi. Journal of Herpetology 15: 77-81.
BULL CM, M DOHERTY, LR SCHUTLE \& Y PAMULA (1994) Recognition of offspring by females of the Australian skink, Tiliqua rugosa. Journal of Herpetology 28: 117-120.

BULL CM, CL GRIFFIN \& GR JOHNSTON (1999a) Olfactory discrimination in scat-piling lizards. Behavioral Ecology 10: 136-140.

BULL CM, CL GRIFFIN \& MV PERKINS (1999b) Some properties of a pheromone allowing individual recognition, from the scats of an Australian lizard, Egernia striolata. acta ethologica 2: 35-42.

BULL CM, CL GRIFFIN, EJ LANHAM \& GR JOHNSTON (2000) Recognition of pheromones from group members in a gregarious lizard, Egernia stokesii. Journal of Herpetology 34: 92-99.

CARPENTER GC \& D DUVALL (1995) Fecal scent marking in the western banded gecko (Coleomyx variegatus). Herpetologica 51: 33-38.

CEI JM (1986) Reptiles del centro, centro-oeste y sur de la Argentina. Herpetofauna de las zonas áridas y semiáridas. Monografía IV. Museo Regionale di Scienze Naturali, Torino, Italy. 527 pp.

CEI JM (1993) Reptiles del noroeste, noreste y este de la Argentina. Herpetofauna de las selvas subtropicales, Puna y Pampas. Monografía XIV. Museo Regionale di Scienze Naturali, Torino, Italy. 949 pp.

COOPER WE Jr (1994) Chemical discrimination by tongueflicking in lizards: a review with hypothesis on its origin and its ecological and phylogenetic relationships. Journal of Chemical Ecology 20: 439-487.

COOPER WE Jr (1998) Evaluation of the swab and related tests as a bioassay for assessing responses by squamate reptiles to chemical stimuli. Journal of Chemical Ecology 24: 841-866.

COOPER WE Jr \& WR GARSTKA (1987) Lingual responses to chemical fractions of urodaeal glandular pheromones of the skink Eumeces laticeps. Journal of Experimental Zoology 24: 249-253.

COOPER WE Jr \& SE TRAUTH (1992) Discrimination of conspecific male and female cloacal chemical stimuli by males and possession of a probable pheromone gland by females in cordylid lizard, Gerrhosaurus nigrolineatus. Herpetologica 48: 229-236.

COOPER WE Jr \& LJ VITT (1986a) Thermal dependence of tongue-flicking and comments on the use of tongueflicking as an index of squamate behavior. Ethology 71: 177-186.

COOPER WE Jr \& LJ VITT (1986b) Interspecific odor discrimination by a lizard (Eumeces laticeps). Animal Behaviour 34: 367-376.

COOPER WE Jr \& LJ VITT (1987a) Intraspecific and interspecific aggression in lizards of the scincid genus Eumeces: chemical detection of conspecific sexual competitors. Herpetologica 43: 7-14.

COOPER WE Jr \& LJ VITT (1987b) Ethological isolation sexual behavior and pheromones in the fasciatus species group of the lizard genus Eumeces. Ethology 75: 328-336.

COOPER WE Jr, WR GARSTKA \& LJ VITT (1986) Female sex pheromones in the lizard Eumeces laticeps. Herpetologica 42: 361-366. 
COOPER WE Jr, P LÓPEZ \& A SALVADOR (1994) Pheromones detection in an amphisbaenian. Animal Behaviour 47: 1401-1411.

COOPER WE Jr, JH VAN WYK \& PLE FN MOUTON (1996) Pheromonal detection and sex discrimination of conspecific substrate deposits by the rock-dwelling cordylid lizard, Cordylus cordylus. Copeia 1996: 839-845.

COOPER WE Jr, JH VAN WYK \& PLE FN MOUTON (1999) Discrimination between self-produced pheromones and those produced by individuals of the same sex in the lizard Cordylus cordylus. Journal of Chemical Ecology 25: 197-208.

DUVALL D, BM GRAVES \& GC CARPENTER (1987) Visual and chemical composite signaling effects of Sceloporus lizards fecal boli. Copeia 1987: 10281031.

ESCOBAR CA, A LABRA \& HM NIEMEYER (2001) Chemical composition of precloacal secretions of Liolaemus lizards. Journal of Chemical Ecology 27: 1677-1690.

FONT E (1996) Los sentidos químicos de los reptiles. Un enfoque etológico. In: Colmenares F (ed) Etología, psicología comparada y comportamiento animal: 197 259. Síntesis Psicológica. Editorial Síntesis S.A, Madrid, Spain.

HETH G, J TODRANK \& RE JOHNSTON (1999) Similarity in the qualities of individual odors among kin and species in Turkish (Mesocricetus brandti) and golden (Mesocricetus auratus) hamsters. Journal of Comparative Psychology 113: 321-326.

LABRA A (1998) Selected body temperatures of seven species of Chilean Liolaemus _izards. Revista Chilena de Historia Natural 71: 349-358.

LABRA A \& HM NIEMEYER (1999) Intraspecific chemical recognition in the lizard Liolaemus tenuis. Journal of Chemical Ecology_25: 1799-1811.

LABRA A, S BELTRÁN \& HM NIEMEYER (2001a) Chemical exploratory behavior in the lizard Liolaemus bellii. Journal of Herpetology 35: 51-55.

LABRA A, CA ESCOBAR \& HM NIEMEYER (2001b) Chemical discrimination in Liolaemus lizards: comparison of behavioral and chemical data. In: Marchelewska-Koj A, JJ Lepri \& D Müller-Schwarze (eds) Chemical signals in vertebrates. Volume 9: 439-445. Kluwer Academic/Plenum Publishers, Krakow, Poland.

LENA JP \& M DE FRAIPONT (1998) Kin recognition in the common lizard. Behavioral Ecology and Sociobiology 42: 341-347.

Associate Editor: F. Bozinovic

Received April 16, 2001; accepted November 18, 2001
LÓPEZ P, A SALVADOR \& WE COOPER Jr (1997) Discrimination of self from other males by chemosensory cues in the amphisbaenian Blanus cinereus. Journal of Comparative Psychology 111: 105-109.

LÓPEZ P, P ARAGÓN \& J MARTÍN (1998) Iberian rock lizards (Lacerta monticola cyreni) assess conspecific information using composite signals from faecal pellets. Ethology 104: 809-820.

MANZUR MI \& ER FUENTES (1979) Polygyny and agonistic behavior in the tree-dwelling lizard Liolaemus tenuis (Iguanidae). Behavioral Ecology and Sociobiology 6: 23-28.

MARTÍN J \& P LÓPEZ (2000) Chemoreception, symmetry and mate choice in lizards. Proceedings of the Royal Society of London B 267: 1265-1269.

MASON RT (1992) Reptilian pheromones. In: Gans C \& D Crews (eds) Hormones, brain and behavior. Biology of Reptilia, Volume 18E: 114-228. The University Chicago Press, Chicago, Illinois.

MASON RT \& WHN GUTZKE (1990) Sex recognition in the leopard gecko, Eublepharis macularis (Sauria: Gekkonidae): possible mediation by skin-derived chemosignals. Journal of Chemical Ecology 16: 27 36.

MAYER MS \& MCLAUGHLIN (1991) Handbook of insect pheromones and sex attractants. CRC Press, Boca Ratón, Florida. 1096 pp. See also the Internet site: http://www.nysaes.cornell.edu/fst/faculty/acree/ pheronet/index.html

MEREDITH M (1999) Vomeronasal organ. In: Knobil E \& JD Niell (eds) Encyclopedia of reproduction, Volume 4: 1004-1014. Academic Press, New York, New York.

NOLDUS (1995) The Observer ®. System for collection and analysis of observational data. V.3. Noldus Information Technology b.v., Wageningen, The Netherlands.

PAUSSE BM, K KRAUEL, B SOJKA \& R FERSTL (1999) Body odor evoked potentials: a new method to study the chemosensory perception of self and non-self in humans. Genetica 104: 284-294.

WALLS SC, A MALTHIS, RG JAEGER \& WF GERGITS (1989) Male salamanders with high-quality diets have faeces attractive to females. Animal Behaviour 38 . 546-548.

WERNER DI, EM BAKER, E DEL C GONZÁLEZ \& IR SOSA (1987) Kinship recognition and grouping in hatchling green iguanas. Behavioral Ecology and Sociobiology 21: 83-89.

ZAR JH (1984) Biostatistical analysis. Prentice-Hall International Inc., London, United Kingdom. 718 pp. 